\title{
ELEMENTOS RETÓRICOS NAS POLÊMICAS RELIGIOSAS DA REFORMA: AS EPÍSTOLAS DE MIGUEL SERVET
}

\author{
ELAINE CRISTINE SARTORELLI* \\ Faculdade de Filosofia, Letras e Ciências Humanas \\ da Universidade de São Paulo
}

\begin{abstract}
RESUMO: Este artigo tem por objetivo comentar algumas características da retórica do século XVI, ilustradas por meio de citações extraídas de dois livros apensos à obra A Restituição do Cristianismo (Christianismi Restitutio), de 1553: as Trinta Epístolas a João Calvino, Pregador dos Genebrinos e a Apologia a Filipe Melanchthon e a seus colegas sobre o mistério da Trindade e sobre os costumes dos antigos. Seu autor, Miguel Servet (1511-1553), pertence ao movimento modernamente conhecido como Reforma Radical.
\end{abstract}

PALAVRAS-CHAVE: Reforma; retórica; estilo baixo cristão; século XVI.

Os Evangelhos sinóticos contam como Jesus delegou aos doze discípulos escolhidos a tarefa de realizar curas e a missão de anunciar a Boa Nova (Mt. 10, Mc 6 e Lc 9), indicando, assim, o papel central que a persuasão pela palavra deveria desempenhar no Cristianismo - religião que não tinha como apelo os laços de sangue ou a tradição dos antepassados, mas que buscou seus primeiros adeptos por meio da conversão. Uma religião que se apóia sobre relatos de milagres, no entanto, permanece na dependência de fatores como a veracidade do narrador e a interpretação do ouvinte. Assim, o debate entre Pedro e Paulo acerca da circuncisão foi apenas a primeira manifestação da tendência para a divisão em facções que fez do Cristianismo uma religião sempre às voltas com polêmicas. Não por acaso, o gênero epistolar de caráter apologético ou diatríbico foi a princípio seu maior veículo, e quase toda a Patrística foi redigida na forma de cartas a comunidades perseguidas ou vacilantes em sua fé. A Patrística prénicena, fonte da teologia servetiana, também serviu-se largamente do formato epistolar: há cartas de Clemente, Inácio, Policarpo, Cipriano e outros, todas com o intuito de 
levar às comunidades "a verdadeira fé", combatendo, ao mesmo tempo, os adversários "heréticos".

Tendo se mostrado tão perfeitamente adaptado à finalidade proposta, o gênero epistolográfico de feições apologéticas foi sempre largamente utilizado pelo Cristianismo. E, num momento de intensa agitação teológica como o período da Reforma, experimentou forte renascimento, propiciado tanto pela facilidade de difusão trazida pela invenção da imprensa quanto pelas circunstâncias históricas, que fizeram da argumentação a mais poderosa arma daqueles que precisavam justificar sua rebeldia diante da Igreja estabelecida. Isso é especialmente válido no que concerne à Reforma Radical, movimento que, contrapondo-se tanto ao Catolicismo quanto à Reforma Protestante, foi a um só tempo obrigado a defender sua doutrina enquanto se protegia de acusações e perseguições de ambos os lados.

Quanto às trinta cartas de Servet a Calvino, que estas tenham realmente sido escritas e enviadas, prova-o o fato de seus originais autógrafos, fornecidos pelo próprio Calvino, terem aparecido em mãos dos inquisidores católicos, a fim de que o autor do livro, que vivia na França sob a falsa identidade de Michel de Villeneuve, confrontado com as mesmas cartas publicadas, mas escritas de próprio punho, não pudesse negar a autoria de todo o livro. Apanhado, Villeneuve confessa ter escrito a Calvino em caráter confidencial, "sub sigillo secreti", assumindo a identidade de Servet, pois pareceu-lhe a ele, Villeneuve, que Servet "dizia coisas tão boas ou melhores que os outros". Uma vez admitida a autoria das cartas, porém, já não havia como negar ser também o autor de Christianismi Restitutio, e, portanto, Miguel Servet. Foi, assim, a publicação das Epistolae Triginta que determinou sua condenação à morte em fogo lento - da qual Servet conseguiu evadir-se para tornar-se, meses depois, vítima de uma fogueira acesa em solo protestante sob a alegação de haver procurado "infectar o mundo" com seu "hediondo veneno herético".

Embora concebidas e escritas para ser realmente enviadas como correspondência, não apenas sigilosa como perigosa, estas Epistolae são antes "discursos epistolares" ou "traités", como são chamadas nas atas do processo inquisitorial; segundo o servetista Angel Alcalá, podem ser consideradas precursoras dos Essais de Montaigne, cuja publicação deu-se em 1580. Como é freqüente na Reforma, o texto não é mais uma littera, mas um sermo ou uma concio (discurso de características deliberativas, considerada por Erasmo o tipo de escrita ideal para o pregador cristão).

Como recorda Peter Matheson (Matheson, 1998, p. 1), todas as ações da Reforma ("a luta contra os abusos morais e educacionais, a erradicação de erros antigos, a queda dos tiranos e dos sicofantas") "necessariamente envolviam polêmica". Uma polêmica muitíssimo mais urgente e de conseqüências muito mais graves do que as 
disputationes escolásticas, com suas teses e contra-teses de caráter acadêmico. $\mathrm{O}$ rígido e intelectualizado sermão temático escolástico, baseado em definitio e demonstratio, e teorizado em manuais de artes praedicandi, foi, portanto, substituído por escritos menos estruturados, mas muito mais impactantes. Um texto solidamente arranjado como o de Tomás de Aquino, por exemplo, em nada se assemelha aos arroubos de um indignado Lutero ou à paixão messiânica de um Tomás Müntzer. Longe de ser um jogo de intelectos, as disputas da Reforma podiam apresentar-se, literalmente, como uma questão de vida ou morte.

Se a linguagem medieval, o cursus, tinha seu ritmo a ser respeitado, na Reforma a oralidade das línguas vernáculas interferiram mesmo na prosa em latim. E se o dilema inerente da prosa medieval fora formalismo versus invenção, na Reforma a questão principal era a de como fazer um discurso de máxima eficácia persuasiva. Assim, a fórmula escolástica an sit, calcada num verbo de ligação, foi rápida e bruscamente substituída por orações com verbos incisivos e mesmo chocantes. Como exemplo, vejamos o que Lutero escreveu acerca do Papa:

Nós, com uma boa consciência, ensinamos e pregamos contra ele, ousamos cuspir nele, evitá-lo e fugir dele como do próprio diabo, removêlo de nossos corações e afundá-lo nas profundezas do inferno.

Apresentando como princípio indiscutível a autoridade da Letra, a Reforma fez com que todas as normas então em voga fossem debatidas à luz do critério escriturístico. Por meio de apologias, panfletos populares com desenhos ou livros eruditos, todos os públicos eram confrontados com a "Verdade", e convidados a agir como juri da causa reformista, enquanto as personagens bíblicas serviam de testemunha contra os réus, isto é, os "papistas".

Se a atitude acima invoca imediatamente o gênero judiciário, outra, pararela, leva imediatamente a pensar no deliberativo, uma vez que é trazido à baila o campo semântico do campo de batalha. Isso é especialmente válido no que diz respeito à Reforma Radical, mas vale também para reformadores como Lutero, cujo escrito De Captivitate Babyloniae conduzia o leitor a pensar no Papa como o Dragão do Apocalipse, contra o qual a batalha se faz necessária para a implantação do Reino. A linguagem da Reforma é, portanto, incontestavelmente militante. Como nos lembra Girardin (Girardin, 1979, p. 85), na Reforma escrever significava necessariamente tomar posição face a certos adversários, colocar-se quanto à tradição, à Escolástica e à própria Reforma. Implicava, assim, em tomar assento num dos lados dos colóquios interconfessionais. Para tanto, fazia-se preciso identificar os pontos polêmicos, descre- 
ver as posições adversárias e travar um diálogo com elas. Nada, portanto, mais distante de nossa visão contemporânea de "eu lírico" que esse engajamento.

O século XVI foi ainda extraordinariamente inventivo em produzir novos estilos; sermões, dramas, catecismos, hinos, panfletos, apologias, comentários, cartas, sátiras, traduções e profecias tomaram, com impressionante rapidez, o lugar do antigo tomo teológico escolástico em latim medieval. Nem sempre, porém, a escrita reformista pode ser classificada como literatura, no sentido estrito e acadêmico da palavra. E ainda que possa ser estudada do ponto de vista literário, a produção quinhentista nem sempre se deixa rotular; se em Cícero, por exemplo, a regra era que, uma vez escolhido um estilo, não se lhe deveria incorporar estratégias apropriadas a outros estilos, no século XVI encontravam-se facilmente improvisações estilísticas e mesclas de formas e gêneros. Se, na Idade Média, os próprios reis eram iletrados, e, por isso, a inuentio perdera espaço para a imitatio, com regras fixas e fórmulas prontas que facilitavam tanto para o leitor quanto para o escritor, na Reforma a informação impressa em línguas vernáculas difundiu-se a tal ponto que surgiram casos como o de Argula von Grumbach, uma mulher que não sabia latim nem tinha qualquer formação acadêmica ou teológica, mas, ainda assim, publicou seus escritos reformistas. O próprio Servet pode ser considerado um produto do século XVI, na medida em que, médico de profissão e sem jamais haver feito parte de uma ordem religiosa, utilizou-se das recentíssimas edições que Erasmo e Beato Renano haviam publicado dos autores patrísticos para atacar nada menos do que o dogma trinitário e a prática do batismo infantil.

Nas trinta cartas enviadas a Calvino, assim como na Apologia, Servet expõe, de forma sistemática, todos os principais pontos de sua doutrina, já fartamente explorados em Christianismi Restitutio, mas agora dirigindo-se diretamente a outros teólogos, com os quais sustenta longas polêmicas e aos quais procura convencer, ao mesmo tempo em que se defende de acusações que lhe foram feitas. Por isso, não se limita a expor, mas debate, refuta e procura inverter os argumentos dos adversários, utilizando-os contra eles próprios. Nesse sentido, o diálogo de Servet não se dá apenas com Calvino e Melanchthon, mas com toda a Reforma. Ademais, ao publicar suas cartas, Servet transforma Calvino de destinatário em intermediário entre ele, autor, e todo o protestantismo como movimento.

O fato de publicar esses escritos epistolográficos revela ainda que Servet queria dar-lhe um novo status - de bate-boca privado a polêmica de alcance internacional. Publicadas, suas cartas ganharam não apenas visibilidade e permanência, como obtiveram ainda o empréstimo da autoridade conferida à letra impressa. 


\section{Inuentio et dispositio}

No contexto da retórica cristã, cabe à exegese escriturística a provisão de topoi para a elaboração do texto. No humanismo erasmiano, as regras da gramática, os princípios da retórica e a escolha dos topoi são instrumentos para a gradual compreensão da Escritura em três níveis de significação crescente (metódos histórico, tropológico e alegórico, respectivamente). Segundo Erasmo, a inuentio fornece a matéria para o discurso, e, por isso, compara-se aos ossos do corpo, que devem ser firmes ou tudo o mais desmorona. A dispositio, por sua vez, assemelha-se aos nervos, pois, assim como estes unem as partes do corpo, aquela mantém unidas as partes do discurso.

Os loci de Servet são os mesmos de outros autores cristãos: Trindade, batismo, Ceia, Igreja etc. Sua compreensão de cada um desses temas, entretanto, diverge radicalmente da ortodoxia; por isso, Servet precisa defender-se também como intérprete, demonstrando que, se a autoridade mesma dos textos limita sua interpretação, serve, por outro lado, para mostrar os erros alheios. Quando pensa a Trindade, por exemplo, afirma estar tratando da Trindade de Irineu, Clemente e Tertuliano, ao passo que os outros, católicos e protestantes, pensam-na nos termos de Agostinho ou de Pedro Lombardo.

Pela razão de que precisa defender todas as suas posições, Servet não parece fazer propriamente uma escolha de topoi, mas um catálogo deles. Se nas Epistolae ad Caluinum há cartas que abordam apenas o tema do livre-arbítrio ou da organização eclesiástica, por exemplo, na Apologia todos os temas tratados na Christianismi Restitutio retornam, embora alguns sejam apresentados de forma muito mais extensa que outros.

Quanto à dispositio, nota-se, especialmente na Apologia, uma organização que mescla circularidade e linearidade, ou seja, os temas retornam, mesmo quando outros, novos, foram introduzidos, e várias expositiones são intercaladas às probationes, de maneira que, ainda que o texto avance, parece estar sempre repetindo os mesmos argumentos, acrescentando-lhes, porém, algo de novo, uma gradatio. O tema da Trindade, por exemplo, vem em "camadas", ou em "espiral": primeiro é introduzido polemicamente, para em seguida ser exposto por intermédio dos livros patrísticos, depois novamente rebatido com relação ao pensamento dos "magos e maniqueus" e posteriormente explicado de novo, para ainda ser retomado na conclusão.

\section{Sermo}

Em contraste com a retórica clássica, o Cristianismo desenvolveu, desde os primórdios, um estilo despojado e bastante cru, chamado, precisamente, de "estilo 
baixo cristão". Nele, a simplicidade, identificada aqui com credibilidade, passa a ser o atributo mais desejável e, como nos lembra Auksi (Auksi, 1995, p. 5), "torna-se uma proclamação espiritual". Assim, escrever de forma simples, sem artifícios ou adornos, é a virtude mais atraente que um autor cristão pode possuir, uma vez que, assim, os ouvintes/leitores seriam capazes de medir a qualidade moral do orador sem distrações estéticas; a substância, portanto, opõe-se à forma em vez de esta servir de veículo para a total expressão daquela. Tal visão perpassou toda a literatura cristã; Jerônimo, por exemplo, valorizou a rusticidade mais do que a eloqüência, considerada pecaminosa; em seu Prefácio da Vulgata, afirmava que o exterior rude das Escrituras na verdade servia disfarçava um estilo não menos perfeito que o encontrado na literatura pagã, e que "a Santa Escritura é como um belo corpo encoberto por uma roupa suja". Segundo Basílio, o que os cristãos escrevem é "verdadeiro em substância, embora inculto em estilo". Isidoro, por sua vez, afirma que a sententia veritatis da Escritura opõe-se à compositio verborum, pois "devemos amar a verdade, não as palavras".

A Reforma defendia o mesmo ideal de simplicidade; assim, "a tarefa do teólogo", segundo Calvino, "não é deleitar os ouvidos com garrulice, mas fortalecer as consciências pelo ensino de coisas verdadeiras, certas e úteis" (IRC.I.14.4).

Essa presumida superioridade do estilo baixo deve-se à crença de que um discurso inspirado pela própria Divindade não pode ater-se às normas e regras ditadas pela retórica. Quando o autor serve de veículo para a transmissão da Verdade, sua forma deve ser, necessariamente segundo esta visão, contra a arte, ou seja, sem quaisquer artifícios. Faz-se necessário lembrar aqui que, ao abandonar a retórica clássica para adentrar as polêmicas religiosas, o leitor contemporâneo não deve perder de vista o fato de que está ingressando no terreno das causas apodíticas, cuja garantia, inquestionável e absoluta, é a Bíblia, seguida pelos textos patrísticos. As probabilidades ciceronianas neo-acadêmicas, portanto, dão lugar a nada menos que à Verdade. E as palavras usadas para tratar da Verdade devem ser tão pouco discutíveis quanto ela própria.

O sermo servetiano insere-se no genus humile cristão. É significativo (e programático) o número de vezes em que Servet repete que, quanto à linguagem e ao estilo, interpreta a Bíblia e escreve sua teologia "sine tropo", "sine fuco", "sine sophismate". Na Apologia, ao citar Simão Mago (e Simão Mago era o apelido que havia dado a Calvino), escreve:

Retórico era ele, sofista, eloqüente, disputando para vencer com sua eloqüência. $\mathrm{O}$ mesmo de vos incumbis vós todos, que só vos satisfazeis com o lenocínio de um discurso ensaiado (Christ.Rest. 674). 
E prossegue:

Mas o Espírito Santo nunca falou por tais meios. Nunca fez uso de palavras e de artifícios polidos com colorido variado, pois ama a palavra simples e comum. Também Paulo ensina que a força da pregação de Cristo é esvaziada pela eloqüência do discurso. Por isso, vossa retórica afetada e sofística revela enfraquecimento da verdade e conduz aos várias encantos da falsidade (Christ.Rest. 674).

$\mathrm{O}$ uso da palavra falsitas, intencional e proposital, insere-se aqui em todo o contexto da Apologia, iniciada precisamente com a frase "de dupla falsidade me acusas como réu" e em cujo primeiro parágrafo aparecem ainda o adjetivo "falsus" e o advérbio "false", como imputações às quais a Apologia dará a resposta, protegida pela "suma verdade". Falsitas, portanto, aparece aqui quase como um termo técnico, empregado sempre, desde o Cristianismo primitivo, como "inimiga da verdade". Já Isidoro a associava não apenas à inverdade mas também aos "ornamentos lingüísticos". Assim, a falsitas está aqui identificada com o sofisma e o tropo dos retores.

Pertencentes, de modo geral, ao gênero deliberativo, mas com traços judiciais, por vezes, as trinta cartas dirigidas a Calvino e a Apologia versam, todas elas, sobre causas públicas e polêmicas, o que torna dispensável um longo exórdio. A técnica empregada é definir de imediato a posição do adversário com o fito de apontar já à primeira vista o fator de discórdia. Esse mecanismo, largamente utilizado também por Calvino, recebeu o nome de "polarização do assunto". Todas as Epistolae, portanto, começam in medias res e polemizando, como se pode ver pela transcrição do primeiro parágrafo de algumas delas:

I: Confessas ter dito que aquele Jesus Nazareno, crucificado por nós, miseráveis, somente de nome é filho de Deus, mas que em realidade não é filho. Porque não cres que a verdadeira razão de que este homem seja chamado filho de Deus consista em que seja verdadeiramente gerado da substância de Deus; mas dizes que é filho por certa metáfora, porque está nele o outro filho invisível, como um raio de luz separado. Despedaças a Deus num grande monstro, destróis o filho verdadeiro, e crias novos deuses (Christ.Rest., 577).

IV: Julgas ser crassa heresia minha essa de crer que o homem Jesus é o filho verdadeiro e natural de Deus, e que seu próprio corpo estava prefigurado na Palavra e nos anjos. Crassa por isso: porque atribuo algo 
visível e perceptível à Palavra, ao espírito e aos anjos. Essa fé crassa abraçavam outrora os rudes discípulos, e abraçam-na agora os verdadeiros cristãos, embora dela se riam os sublimes matemáticos e os metafísicos. Tão veemente é a ilusão que já ninguém reconhece a verdadeira manifestação de Deus (Christ.Rest. 583).

XIX: Uma vez que não distingues bem entre o pagão, o judeu e o cristão, eu te chamarei a atenção para umas poucas coisas a esse respeito (Christ.Rest., 623).

XXVIII: Não compreendeste de verdade que tarefas correspondem aos bispos e aos presbíteros nas confissões e nas confirmações (Christ.Rest., $657)$.

Quanto à estrutura, a epistolografia servetiana assemelha-se à dialexis diatríbica paulina: primeiramente o leitor/destinatário é diretamente apostrofado (Calvino ou Melanchthon) e geralmente adjetivado ("tu, que és gramático"; etc.). Sua opinião é presumida ("dirás que", "responder-me-ás que"), dirigem-se-lhe perguntas ("não vês que?", "acaso ignoras que?") e seguem-se admoestações retóricas ("lembra-te de que” etc.).

Tendo estabelecido de início e sem rodeios o tema a ser tratado, o método empregado por Servet nas Epistolae será sempre o mesmo: parafrasear Calvino ("dizes que", "pensas que" etc.), para em seguida refutá-lo (com argumentos próprios, patrísticos e escriturísticos) e, por fim, apresentar a sua opinião do assunto em questão. Assim, o caminho traçado é o de primeiro dissuadir para depois persuadir. Na fase da dissuasão, recorre-se a expedientes satíricos e certo humor cruel aparece constantemente a serviço de táticas para ridicularizar o adversário; Calvino é chamado de "Simão Mago", "maniqueu", "pedra e tronco". Na Epístola VIII, por exemplo, Servet escreve ao oponente:

Admiro-me sinceramente de que sendo homem em teu juízo perfeito, como te jactas de ser, sejas impelido para mar tão profundo por um vento tão brando, arremetendo contra tantos rochedos e monstros (Christ.Rest., 595).

A Melanchton, professor de grego e considerado grande humanista, Servet dirige ironias mais sutis: 
Era dever vosso, que sois gramáticos e professais um método apropriado de falar, empregar os vocábulos em suas acepções próprias (Christ.Rest., 676).

Lembre-se ainda que, na literatura cristã epistolar, a autoridade da fala é garantida pelo apostolikon, a auto-apresentação do apóstolo, cujo discurso em primeira pessoa é a garantia da verdade da fala. O ethos do apóstolo/orador (que, apresentando-se como portador da verdade, reserva para seus adversários o papel de "falsos mestres"), fundamenta a legimidade do discurso.

Dentro desse contexto é que se faz necessário ressaltar a importância da utilização do pronome eu no texto, uma vez que sua função é claramente apologética: o autor declara-se, posiciona-se, expõe-se. Servet, que não colocou seu nome na capa do livro, está declarando sua autoria num texto permeado pelos pronomes ego, me, mihi e por verbos conjugados na primeira pessoa do singular.

A utilização da primeira pessoa gramatical em textos religiosos indica ainda que o autor está se posicionando como aquele que "é enviado". Desde os tempos apostólicos, o "enviado" (incluindo-se aí o próprio Cristo) deve também apresentar-se como tal e recomendar-se como exemplo, opondo-se aos "falsos mestres". Assim, Paulo apresenta sua biografia, ou seja, sua origem judaica, sua conversão, seus milagres, suas tribulações e perseguições, como quem apresenta uma prova de veracidade diante do júri. Como bem assinala Berger (Berger, 1998, p. 245), "em Paulo o autotestemunho se torna auto-recomendação", ressaltando ainda que a origem dessa técnica pode ser atribuída à apologética helenística. $\mathrm{O}$ mais conhecido trecho autobiográfico com tendência apologética aparece em Gálatas, compreendido entre 1, 12 e 2, 14.

Servet constrói toda a sua argumentação a partir da premissa de que "o Mal apoderou-se da Igreja” em 325, ano do Concílio de Nicéia. Portanto, todo o corpus christianum que se formou a partir de então deve ser descartado. Apoiado em seus sólidos conhecimentos de grego e de hebraico, Servet se volta para as Escrituras e para os "doutores antigos" (ou seja, pré-nicenos), na tentativa de remover desses textos as camadas de interpretações que lhe foram acrescentadas pela "tradição". É significativo o número de vezes em que menciona a palavra "abuso", referindo-se a distorções da doutrina cometidas pela deturpação das verba. $\mathrm{O}$ abuso teológico, portanto, origina-se no abuso dos termos. Na Apologia, Servet expressa sua indignação contra Melanchthon e seus colegas num trecho em que traços da linguagem oral tornam ainda mais veemente sua oratória:

Além deste abuso das pessoas, há outro abuso manifesto em figura, forma e imagem. Há abuso, igualmente, no próprio significado da pala- 
vra Logos. Há abuso no vocábulo sabedoria. Há abuso na acumulação suposital. Há abuso em homousios. Abuso na comunicação de idiomas. Abuso na visão de Deus. Abuso nos termos gerar e nascer. Há abuso, por fim, no próprio vocábulo filho. Todos estes vocábulos de vossos trinitários estão faltos de Escrituras, são ilusões de demônios e foram deturpados por meio do abuso. Omito aqui outros abusos teus quanto às palavras dos sacramentos, assim como tuas retoricazinhas para deleite de teus devotos. Na aceitação do batismo infantil, na justificação e na adoção, quanto abuso! Na palavra inferno, quanto abuso! Quanta ignorância! Não entendeis nem a vida, nem a morte, nem o inferno, nem a verdadeira libertação do Cristo (Christ.Rest., 676).

Na Epístola XV, mais um parágrafo notável, em que se condensam várias características da epistolografia servetiana:

O que dizes de brincadeira sobre o sacramento da penitência é indigno de resposta, pois me argumentas com base em termos criados segundo teu capricho, o que eu detesto (Christ.Rest., 616).

A argumentação servetiana, portanto, baseia-se na legitimação garantida pela correta interpretação dos termos; Servet professa essa sua verdade na primeira pessoa:

Por isso, Filipe, reflete numa única coisa: que eu não induzo a quaisquer novidades no uso dos termos, que eu não emprego nenhum sofisma, que eu não cometo abuso algum quanto às palavras das Escrituras, como vós fazeis. Eu não deturpo nenhum passo da Escritura, e a nenhum violento. Em tudo procedo sincera, simples e abertamente. Se tivesses uma migalha de inteligência, isso já seria para ti um grande argumento de verdade. Ofende-vos que eu fale contra vosso costume. Como se eu não tivesse de ter muito maior cuidado em falar de acordo com as Sagradas Escrituras! A tal ponto estais enfeitiçados por vossos costumes perversos que não vos dais conta de que, para Deus, sois odiosos sofistas (Christ.Rest., 676).

Mas Servet tem ainda mais um motivo para acreditar-se integralmente ao lado da verdade. Por crer que a defesa de sua causa é uma batalha contra o Anticristo, Servet identifica-se com o guerreiro Arcanjo Miguel, cuja data comemorativa, 29 de setembro, é precisamente o dia de seu aniversário e a data escolhida para a impressão da primeira página da Restitutio, em cuja capa figuravam, em grego, as palavras "e havia 
guerra no céu" (que, para qualquer leitor do Apocalipse, remetem imediatamente ao restante do versículo: "Miguel e seus anjos lutavam contra o Dragão"), e, em hebraico, as palavras "e Miguel apareceu no céu", extraídas de Daniel. Mas Servet tem a audácia de dizê-lo a Calvino ainda mais abertamente, na vigésima Epistola:

Eu trabalho incessantemente pela restituição desta Igreja, e tu te aborreces comigo porque me imiscuo nesta guerra de Miguel e desejo que todos os homens piedosos façam o mesmo. Mas lê este passo atentamente e verás que haverá homens que lutarão então, expondo sua vida à morte de sangue em testemunho de Jesus Cristo, como João ensina aí abertamente. Homens que são chamados anjos, como consta nas Escrituras. Tanto mais que no próprio céu os anjos bons guerreiam contra os dragões e outros anjos maus do Papado. Ou não crês que também o Papado é defendido por seus anjos? Por isso não pode ser destruído sem guerra de anjos (Christ.Rest., 628).

Servet, portanto, constrói sua identidade de orador sobre os fundamentos fornecidos: 1. Pelos argumentos de autoridade extraídos dos cristãos primitivos; 2. Pela sua confissão de proceder em tudo "sincera, simples e abertamente"; e 3. Pela sua identificação com o Miguel apocalíptico. O apostolikon de Servet é, portanto, seu ethos de cristão que se apóia no cristianismo puro, que age e fala com simplicidade e que está encarregado da tarefa messiânica de lutar como e para Miguel. Tudo isso, pois, autentica e legitima seu texto.

Mas se este é o remetente, quem são os destinatários? É fato que Servet ataca Calvino diretamente nas Epístolas, assim como Melanchthon na Apologia; mas, certamente, não são eles seus únicos interlocutores. Prova-o a facilidade com que o texto alterna "tu" e "vós", como neste trecho da Apologia:

Sem tropo, não és capaz de conceder-me que este homem seja filho de Deus. Nada é pronunciado entre vós que não esteja envolto por algum sofisma (Christ.Rest., 677).

Servet está, portanto, travando um diálogo com toda a Reforma, e por isso a publicação das cartas. Deste ponto de vista, uma das cartas mais interessantes é a de número XXVII, na qual Calvino serve de pretexto para que Servet refute alguns pontos de discordância com os anabatistas.

Outro dado digno de nota: na Epístola XXV, Servet dirige (nominalmente a Calvino) o seguinte imperativo: 
Lê o último parágrafo do Livro Segundo, sobre a justiça do Reino de Cristo (Christ.Rest., 650).

O trecho a que ele se refere pertence às páginas 327 a 336 da Christianismi Restitutio. Ou seja: não se trata de um destinatário de uma carta, mas de um leitor que tenha o livro à mão; provavelmente qualquer leitor de ambiente protestante (o público-alvo de Servet).

A figura de linguagem mais utilizada pelos autores cristãos é a metáfora, que, segundo Auksi (Auksi, 1995, p. 135) tem o poder de "tornar o imaterial palpável e o sublime mistério, coloquial”. Paulo a utiliza em larga escala: há metáforas agrícolas (Rm. 11); de escravidão (Gl. 3,23); militares (Rm 6, 13); comerciais (Ef. 1, 14); sacrificiais (Fil. 2, 17) e atléticas (I Cor. 9, 24-27). Servet, como todos os demais, apropria-se desse vocabulário, e lança mão das conhecidas metáforas do pastor e das ovelhas, do plantio e da colheita, da luz e das trevas, do alimento e da bebida etc. Como exemplo, pode-se citar um passo da Epístola XII:

Desse modo, de um grão pequeno fez-se uma árvore grande (Christ.Rest., 608).

Outro recurso que pode ser encontrado nas cartas servetianas é a utilização das sententiae, não propriamente como o brinde que deve ser oferecido ao destinatário preconizado pela teoria epistolar, mas antes como elemento de argumentação apologética, à maneira paulina. Extraídas todas da Bíblia, as sententiae de Servet são do tipo fartamente encontrado na literatura sapiencial judaica, ou nas formulações simples que servem de "moral da história" às parábolas evangélicas. Como exemplo do primeiro tipo pode-se citar um trecho da Epístola XIX, na qual Servet afirma, com Jó, 28, que:

A todas as gentes foi dada, desde o princípio, esta regra de sabedoria: o temor de Deus é sabedoria, e afastar-se do mal, inteligência (Christ.Rest., 626).

O segundo tipo pode ser ilustrado com dois exemplos: um da Epístola XXV: "quem não ama, permanece na morte" (Christ.Rest., 652), extraído de I Jo. 3, 14; e, outro, que ecoa palavras do próprio Cristo:

Se alguém for privado de algo por furto, não admitirei que receba o quádruplo, ou o quíntuplo, como autoriza a Lei de rigor: mas que fique 
satisfeito com o seu e não enriqueça com o prejuízo alheio, e que não faça ao outro o que não quer que se lhe faça (Christ.Rest., 654).

Servet afasta-se, assim, da tradição renascentista de compilar "ditos sábios" ou adágios. Essa prática, tão presente no século XVI e da qual Erasmo se orgulhava, tinha, à época, finalidades bastante definidas, como a de servir de exemplo para o aperfeiçoamento do estilo e a de educar moralmente o público, mesclando, dessa forma, estilo e prescrição ética.

Embora as epístolas de Servet, em seu conjunto, possam ser classificadas como deliberativas, há, em vários momentos, passos em que o autor se defende de erros que lhe foram imputados antes de apresentar seus argumentos, em trechos que poderiam ser catalogados como de natureza judicial. Como exemplo, pode-se citar o exórdio da Apologia:

Acusas-me, Filipe, como réu de dupla falsidade. Primeiro, crês falso o que a suma verdade prescreve: que há um homem gerado por Deus, filho verdadeiro, em quem o pai subsiste. Além disso, imputas-me o crime de chamar Irineu, além de outros doutores antigos, em minha defesa falsamente, quando afirmo que eles pensavam exatamente isto: que no Verbo não há distinção real, mas Cristo em Deus. Este, que é o mais certo e o mais sagrado dos dogmas, não depende de Irineu nem de oráculos humanos, mas de todas as coisas divinas compreendidas sinceramente, sem sofisma algum (Christ.Rest., 671).

As epistolae de Servet, portanto, detêm-se em grande parte no genus humile, próprio da argüição. Não há muitos períodos longos ou circulares, havendo antes a predominância de orações coordenadas ou de períodos curtos e lineares. Como é próprio da expositio, a estrutura sintática costuma ser bastante simples, repetitiva, pleonástica. A presença exaustiva de conectivos é típica da prosa do século XVI, mas ainda mais característica das polêmicas, como se o autor estivesse de fato num colloquium e não quisesse permitir ao opositor nenhuma possibilidade de "assalto ao seu turno". Outra técnica muito utilizada é a justaposição de uma série de palavras separadas por vírgulas, criando um efeito staccato que permite grande realce a cada um dos termos. Como ilustração, mais um passo da Apologia:

Esta era originalmente a trindade: era Deus Pai, imensidão inacessível, incompreensível, luz invisível. Nessa imensidão era o Verbo, luz, pessoa do Cristo; primeiro, idéia oculta; em seguida, Palavra manifesta. Era o 
selo divino posto como sinal, certa resplandescência da glória de Deus. Era luz aparente de luz não aparente, e permanecia luz na luz, luz visível feita de luz invisível, acessível de inacessível, manifestação divina para a geração substancial desse homem (Christ.Rest., 704).

A parataxe, ou seja, a colocação de unidades lado a lado, sem subordinação, é, de fato, um dos mais fortes e marcantes traços da prosa servetiana. Além disso, há, como em Paulo, um ritmo impresso por essas seqüências ora binárias, ora ternárias, ora múltiplas. E, ainda mais importante, há, no conjunto, uma idéia de gradação. Exemplos:

Não havia em Deus nenhum monstro, nenhuma dissecção, nenhuma distinção real; mas a glória eterna do homem Jesus Cristo, filho de Deus, nele desde a eternidade e que na eternidade existe pessoal e substancialmente (Christ.Rest. 579);

e ainda:

Mas diz-se que a fé morre lentamente quando lhe são tiradas as vestes, cessam os alimentos, enlanguescem as obras, esfria-se a caridade, revigora-se a carne. Irrompem os vícios, extingue-se o Espírito, morre o Cristo (Christ.Rest., 632).

Assim como não se demoram no exórdio, as cartas de Servet, em geral, tampouco apresentam peroração; a função desta, de mouere o leitor, parece estar contida na própria argumentação, sendo o resultado lógico de um processo realizado pelo leitor, não pelo autor. Algumas sequer apresentam conclusão; terminada a argüição, termina também a epístola.

Concluída a argumentação, portanto, as epístolas de Servet não retomam o tema numa tentativa de reelaboração do tema. Algumas, como a primeira, fecham-se com a expressão de um desejo:

Esteja Jesus Cristo contigo, para que o conheças bem. Amém (Christ.Rest., 579).

Outras, como a de número treze, simplesmente encerram-se com uma acusação:

Mostra-se ridícula tua teoria da fé como conhecimento e mais mágica ainda tua alucinação, e desmentida tua acusação (Christ.Rest., 610). 
Outras, por fim, terminam com imperativos, como a vigésima quinta:

Deixa, pois, Calvino, de deturpar-nos aquela Lei, ou de tratar de sua observação em formas tão violentas, como se tratasses com judeus. Que Deus, que nessa Lei se apiedou tantas vezes dos judeus, apiede-se também de ti. Amém (Christ.Rest., 653).

Na Apologia, entretanto, é visível a presença de uma conclusão dramática do texto, feita por meio de imagens impressionantes, que reforçam os pontos principais de tudo o que foi discutido anteriormente, caracterizando uma peroratio.

\section{Verba}

Quer por seu nascimento e propagação sob o domínio romano, quer por ver-se sempre às voltas com algum tipo de dissidência, o Cristianismo encontrou no jargão jurídico um dos mais fecundos campos semânticos para sua expressão. $O$ tribunal de justiça transformou-se em imensa fonte de metáforas, especialmente porque a origem do Cristianismo deu-se no seio da Lei mosaica, o que ocasionou farto número de expressões, tais como: cumprir a Lei, absolvição do pecado, condenação eterna. No século XVI, os leitores foram conclamados a participar como juri num tribunal em que os promotores (os reformadores) fizeram sentar-se no banco dos réus dogmas, crenças e práticas; ou seja, tudo aquilo a que Matheson (Matheson, 1998, p. 6) chama "identidade religiosa e cultural”. Assim, a Europa transformou-se num imenso tribunal em que panfletos e tratados (com todas as réplicas, tréplicas e refutações em regra típicas do período) substituíram os discursos dos advogados, num cenário em que a Inquisição encontrou campo fértil para semear seus tribunais, interrogatórios, acareação de testemunhas, provas e aplicações de penas.

Também Servet serve-se fartamente desse vocabulário, tratando longamente do Juízo, dos testemunhos de fé, de Cristo como nosso advogado etc. O emprego de termos jurídicos parece conferir ainda qualidade ao argumento, especialmente porque o orador/pregador apresenta-se como advogado e campeão de uma causa nobilíssima. Calvino, no célebre prefácio da Institutio, sublinha que não está tomando sua "deffence particuliere", "mais i'entrepens la cause comme de tous les fideles". Melanchthon, na Introdução de sua Apologia da Confissão de Augsburg, afirma, contra "os muitos corações e mentes perturbados" que a sua causa é também a de Jesus Cristo. Servet, em sua identificação com o Arcanjo Miguel, referia-se constantemente à "causa" por que lu- 
tava. Já no Proemium de Christianismi Restitutio conclui assim uma invocação a Cristo:

Tua é esta causa de expor a glória que recebeste do Pai e a do teu Espírito, causa que se me apresentou com certo impulso divino para que dela me incumbisse, uma vez que estava preocupado por tua verdade. Comecei essa incumbência algumas vezes, e agora de novo me vejo obrigado a dar-lhe prosseguimento, porque, em verdade, esgotou-se o tempo, como, a partir da evidência do próprio tema e dos sinais manifestos dos tempos, hei de demonstrar agora a todos os fiéis. Tu nos ensinaste que não se pode ocultar a luz, de modo que ai de mim, se não evangelizar! Trata-se de uma causa comum a todos os cristãos, à qual estamos todos obrigados (Christ.Rest., 4).

Assim, verbos como examinare, intervenire e contendere, pertencentes à alçada legal, são constantes em textos da Reforma; da mesma forma, o verbo constituere, largamente utilizado por reformadores, impõe-se por sua precisão técnica, uma vez que significa a ação do juiz ao fixar a condição de cada uma das partes de um processo.

Apesar da completa oposição de reformadores protestantes e radicais à Escolástica, o debate religioso do XVI não podia ainda prescindir do jargão estabelecido por esta; verbos como inducere, deducere, distinguere, definire e palavras como significatio e similitudo são abundantes nos textos da época.

Quanto ao emprego dos termos técnicos teológicos, há uma distinção vital entre Servet e os demais reformadores, determinada pela diferença de sentido que os dois lados emprestam ao vocabulário. Enquanto os demais teólogos empregam substantia, essentia, natura etc. na acepção comum, com implicações filosóficas e religiosas conhecidas, Servet deve, por sua vez, (re)estabelecer todos esses conceitos à luz de sua interpretação, em cujo auxílio aduz comentários filológicos de hebraico, trechos de autores patrísticos e as correções que os humanistas erasmianos fizeram à Vulgata.

Ainda na questão do vocabulário, é claramente perceptível nos textos reformistas a manipulação dos vários níveis de linguagem. Há todo um linguajar para a doutrina "herética" (com muitos adjetivos e insultos) e outro, bem mais contido, para a sua própria. Ademais, praticava-se largamente o que a Retórica clássica denominava de contentio dignitatis (o elogio daquele a quem se defende) e de reprehensio uitae (censura daquele a quem se ataca). Para Servet, seu tema, a restauração do Cristianismo à pureza primitiva, é "tão sublime por sua majestade quanto fácil por sua clareza e certo por sua demonstração" (vt maiestate sublimis, ita perspicuitate facilis, et demonstratione 
certus). Já os padres católicos são como os "sacerdotes babilônicos", e seus rituais não passam de "pantomima". Calvino, já chamado por Servet de Simão Mago, por sua vez, julga que os "vícios" de anabatistas, libertinos e outros "radicais" não passam de "falsidade manifesta", "amontoado de blasfemias" e "encantamentos de feiticeiros". Enquanto isso, Lutero ironiza seus oponentes com uma linguagem perojativa que não se detém diante do ridículo ou mesmo do escatológico, como quando declarou que todos os porcos da Bavária haviam se mudado para a faculdade de teologia de Ingolstadt ou quando descreve o Papa com as palavras populares para "fezes", "gases" e outras referências anais. Do lado anabatista, Thomas Müntzer afirma que os princípes não desempenhariam qualquer papel no Milênio "porque passaram suas vidas em manjares e bebedeiras, foram desde a adolescência gente muito delicada, nunca tiveram um único percalço em toda a sua vida e não esperam nem desejam vir a ter algum".

Outro dos expedientes mais usados nas polêmicas religiosas da Reforma era o de citar os doutores antigos para comprovar a antigüidade (e, portanto, a confiabilidade) da doutrina que se pretendia demonstrar. Esse recurso tem ainda mais importância no caso de Servet, que pretendia "restituir" o Cristianismo, o que fazia das fontes primitivas e patrísticas seu testemunho mais valioso. Por isso, para apoiar sua argumentação, Servet recorre com freqüência a outros autores, especialmente pré-nicenos, intercalando citações e lançando mão de palavras hebraicas e gregas para elucidar o significado de termos a que a Escolástica teria emprestado novos sentidos, deturpando-as. Essas citações, se não conseguem vencer o adversário com o peso de sua autoridade, deveriam servir ao menos para confundi-lo. Foi com o apoio de um passo de Justino, hoje reconhecidamente apócrifo, que Calvino logrou minar toda a argumentação antitrinitária de Servet.

As citações bíblicas são tão abundantes no texto servetiano que podem ser fartamente encontradas em todas as páginas da Restitutio, incluindo-se as Epístolas. Aqui, como na a prosa homilética do século XVI em geral, citações das Escrituras seguem-se umas às outras em sucessão tão rápida que chegam a invocar a litania dos textos-prova escoláticos.

Muitas das citações escriturísticas trazem apenas o nome do citado, como na Epístola XIX:

É verdadeiro o dito de Cristo: 'se não tivesse vindo e se não lhes tivesse falado, não teriam pecado' (Christ.Rest., 625).

Outras mostram a fonte: 
Também em II Coríntios 13: 'O crucificado em debilidade vive por fortaleza de Deus' (Christ.Rest., 580).

Outra forma de referendar o próprio texto pelo testemunho de outros autores largamente utilizado por Servet é o de lançar mão de longos catálogos de autoridades. Um excelente exemplo aparece na Epístola IV:

Assim consta por Josefo em suas Antigüidades judias. Assim por Enoc, tal como é citado por muitos, e pelo judeu Fílon em seu livro Sobre os gigantes. Assim interpretaram também os setenta anciãos do povo hebreu e outros hebreus. E assim, com os mesmos apóstolos Pedro, Judas e João, entendem Justino, Ireneu, Clemente Romano, Clemente Alexandrino, Tertuliano, Cipriano, Orígenes, Lactâncio, Eusébio e outros antigos (Christ.Rest., 584).

O sermo servetiano é ainda freqüentemente entrecortado por perguntas, algumas puramente retóricas, outras simulando um diálogo com Calvino, como se estivessem num colloquium, o debate público característico da primeira fase da Reforma que perdeu força com o crescimento da intolerância. Uma pergunta, atribuída ao adversário, serve muitas vezes para introduzir um tema sem necessidade de longas digressões. Na Epistola septima, por exemplo, lê-se: "Que responderás a isso?" (Christ.Rest., 594). Outras vezes, como na XIV, repete uma pergunta que Calvino lhe havia feito por meio de textos publicados: "Perguntas-me onde João ensina que somos neste mundo tais qual é o mesmo Cristo" para dar sua resposta: "no capítulo quarto de sua primeira epístola" (Christ.Rest., 611).

A introdução de um argumento por meio da partícula "an”, de sabor típicamente escolástico, reaparece na Reforma com feições bem mais agressivas. Se na Summa Teologica, por exemplo, cada objeção é colocada e refutada simplesmente, sem qualquer colorido emocional, no conturbado século XVI a antiga fórmula medieval ressurge como que transfigurada pelo calor das batalhas.

Um trecho, tão violento quanto interessante, servirá para exemplicar todos esses tipos de "discurso direto" em voga nas polêmicas religiosas quinhentistas e bastante típico de Servet:

Acaso não é isso contínuo mover-se? contínuo produzir-se? gerar-se? aspirar? Enviar? Acaso não são espécies de movimentos? Há duas emanações reais, e não há movimento real? (...)Não será isso para ti moverse? produzir? Gerar? Aspirar? Não eram acaso duas emanações reais? 
Não se fala acaso da confusa implicação de três realidades? de que um é gerado por outro e de que um terceiro provém deles por inspiração? Ou fluxo? Ou derivação? Ou processão? E com toda esta confusão, com esses movimentos, tu ainda não te aquietas? Que é movimento, se a produção não é movimento? Se a emanação não é movimento? Nascer não é mover-se? E respirar? Proceder, que é? (Christ.Rest., 594).

Em suma, as Epistolae Triginta, assim como a Apologia, pertencem, em conjunto, ao genus deliberatiuum, quer pelos temas abordados quer pela forma com que são tratados, uma vez que remetem a causas públicas e polêmicas, solicitando a adesão do leitor. Há muitos passos, entretanto, de feições judiciais bastante evidentes, especialmente na Apologia.

Como no diálogo espontâneo da língua oral ou no sermão inflamado que o reformador lança do púlpito, a prosa servetiana é marcada por repetições, ritmos, antíseses e paralelismos que expressam o caráter persuasivo de que foi revestida. Seu tom ativista por vezes, confessional em outros momentos, revela todo o engajamento de seu autor numa causa a respeito da qual não manifesta nenhuma dúvida. Assim, escritas no "estilo baixo cristão", as Epistolae e a Apologia não se atêm às regras da boa escrita clássica, mas apresentam uma lógica intrínseca que não apenas se revela por si mesma como se mostra na forma com que são escritas. Assim, como o intuito é causar impacto, e não delectare, Servet não recorre a sinônimos, por exemplo, permitindo que seu texto seja marcado por repetições que emprestam à sua prosa a força de suas convicções.

\section{Notas}

* Professora de Língua e Literatura Latina da FFLCH-USP e Doutoranda em Latim do Programa de Pós-Graduação em Letras Clássicas da FFLCH-USP.

1 HILLAR, 1997, p. 279.

2 CAVARD, 1953, p. 126.

3 BAINTON, 1973, p. 169.

4 Calvini Opera, vol. XIV, cit. por Hillar, no inédito Michael Servetus: Intellectual giant, Humanist, and Martyr, cap. 5.

5 ALCALÁ, na Introdução à edição espanhola das Treinta cartas, 1981, p. 40.

6 Sob o peso de sua influência e autoridade, concio substituiu os outros termos para pregação, como sermo, homilia e oratio, informa O'Malley, 1993, cap. IV, p. 42. 
7 Ibid., 203, n. 57.

8 GIRARDIN, 1979, p. 85.

9 JONES, 1995, p. 20.

10 MATHESON, 1998, p. 53-4.

11 A primeira tradução latina de Irineu data de 1526, realizada por Erasmo. Tertuliano, editado por Beato Renano, só apareceu em 1528, informa Bainton, 1973, p. 57.

12 HOFFMAN, 1994, p. 136.

13 Ibid., p. 136-7.

14 AUKSI, 1995, p. 16.

15 Ibid.

16 Ibid.

17 Theologo autem non garriendo aures oblectare, sed vera, certa, utilia docendo, conscientias confirmare propositum est.

18 AUKSI, 1995, p. 99.

19 HIGMAN, 1967, p. 17.

20 BERGER, 1998, p. 244.

21 Ibid., p. 234.

22 Ver GIRARDIN, 1979, p. 197 a 201.

23 HIGMAN, 1967, p. 106.

24 MATHESON, 1998, 189.

25 Ibid., p. 183 a 214.

26 Cohn, 1981, p. 199.

27 BAINTON, 1973, p. 194.

28 O’MALLEY, 1993, VIII, p. 90.

\section{REFERÊNCIAS BibLIOGRÁFICAS}

AUKSI, P. Christian Plain Style: the evolution of a spiritual ideal. Montreal \& Kingston \& London \& Buffalo: McGill-Queen's University Press, 1995.

BAINTON, R. Servet, el hereje perseguido. Trad. de Angel Alcalá. Madrid: Taurus Ediciones, 1973.

BERGER, K. As Formas Literárias do Novo Testamento. Trad. de Fredericus Antonius Stein. Bíblica Loyola - 23. São Paulo: Ed. Loyola, 1998.

CAVARD, P. Le procès de Michel Servet à Vienne. Grenoble: Jean Vittoz, 1953. 
COHN, N. Na senda do Milênio. Milenaristas revolucionários e anarquistas místicos da Idade Média. Trad. de Fernando Neves e António Vasconcelos. Lisboa: Editorial Presença, 1981.

GIRARDIN, B. Rhétorique et Théologie. Calvin: Le commentaire de l'Epître aux Romans. Théologie Historique 54. Paris: Éditions Beauchesne, 1979.

HIGMAN, F. The Style of John Calvin in his French polemical treatises. London: Oxford University Press, 1967.

HILLAR, M. The case of Michael Servetus (1511-1553) - The Turning Point in the Struggle for Freedom of Conscience. Texts and Studies in Religion - volume 74. Lewiston, NY: The Edwin Mellen Press, 1997.

HOFFMANN, M. Rheoric and Theology: The Hermeutics of Erasmus. Toronto: University of Toronto Press, 1994.

JONES, S. Calvin and the Rhetoric of Piety. Columbia Series in Reformed Theology. Louisville: Westminster John Knox Press, 1995.

MATHESON, P. The Rhetoric of Reformation. Edinburgh: T\&T Clark, 1998.

O'MALLEY, J. Religious culture in the Sixteenth Century. Hampshire: Variorum, 1993.

SERVET, M. Treinta cartas a Calvino. Sesenta signos del Anticristo. Apología a Melanchton. Trad. de Angel Alcalá. Madrid: Editorial Castalia, 1981.

SERVETUS, M. Christianismi Restitutio. Frankfurt: Minerva, 1966 (edição fac-símile da de von Murr, de 1790).

SARTORELLI, Elaine C. Rhetorical Elements in the Religious Polemics of the Reformation: the Epistles by Michael Servetus

ABSTRACT: This paper intends to comment some features of the Rhetoric of the 16 th Century present in the Reformation debates, illustrated by quotations from two books appended to the work Christianismi Restitutio (1553): the Thirty Epistles to John Calvin and the Apology to Phillip Melanchthon and his colleges on the mystery of the Trinity and on the ancient practices. The author, Michael Servetus (1511-1553), is one of the most important names of the movement nowadays called Radical Reformation.

KEY WORDS: Reformation; Rhetoric; christian plain style; $16^{\text {th }}$ Century. 